\title{
Water acquisition, sharing and redistribution by roots: applications to agroforestry systems
}

\author{
J. Bayala $(\mathbb{D} \cdot$ I. Prieto
}

Received: 2 April 2019 / Accepted: 14 June 2019 /Published online: 26 June 2019

(C) The Author(s) 2019

\begin{abstract}
Aims In the face of problems caused by 'intensive agriculture' dominated by large areas of monocultures, mixed intercropping mimicking natural ecosystems has been reported to constitute a viable solution to increase and stabilize productivity. When designing such systems, root niche separation was thought to be a prerequisite to optimize production.

Methods This paper reviews the beneficial and adverse effects of trees and crops on water acquisition and redistribution in agroforestry ecosystems using the concepts of competition and facilitation between plants in link with root functional traits.

Results The results of the review showed that the reality was more complex leading agroforestry practitioners to adopt management practices to induce a separation in root activities thus avoid competition, particularly for water. Water uptake by plant roots is triggered by the water potential difference between the soil and the atmosphere when leaf stomata are open and depends largely on the root exploration capacity of the plant. Thus, root water uptake
\end{abstract}

Responsible Editor: Remi Cardinael.

J. Bayala $(\bowtie)$

World Agroforestry (ICRAF), ICRAF-WCA/ Sahel Node, BP

E5118 Bamako, Mali

e-mail: j.bayala@cgiar.org

I. Prieto

Departamento de Conservación de Suelos y Agua, Centro de Edafología y Biología Aplicada del Segura - Consejo Superior de Investigaciones Científicas (CEBAS-CSIC), Murcia, Spain dynamics are strongly related to root-length densities and root surface areas. In addition, plants with deep roots are able to lift up or redistribute water to the upper layers through a process known as hydraulic lift, potentially acting as "bioirrigators" to adjacent plants. The redistributed water could be of importance not only in regulating plant water status, e.g. by enhancing transpiration, but also in increasing the survival and growth of associated crops in mixed systems.

Conclusions Even though some more work is still needed to assess the volume of water transferred to neighbors, hydraulic lift could constitute an ecological viable mechanism to buffer against droughts and ensure productivity in regions with erratic rainfall. Giving the difficulty in measuring the above-mentioned aspects in the field, modeling of some of the most relevant parameters to quantify them might inform the design of future empirical studies.

Keywords Ecosystem services $\cdot$ Hydraulic lift $\cdot$ Mixed cropping $\cdot$ Productivity $\cdot$ Sustainability

\section{Introduction}

In the face of the world current challenges to sustain good living conditions including increasing population numbers, a changing climate or the degrading agro-ecosystems associated with a declining agricultural productivity, there is a need for approaches that could ensure food security. Indeed, 'intensive agriculture' is dominated by large areas of high-yielding monocultures, i.e. cultures using a single 
species, that are resource-consuming and have led to many environmental problems that intercropping could help to address (Brooker et al. 2015; Machado 2009). For instance, agroforestry or the combination of trees with agricultural crops or pasture, was listed among the climate smart technologies (Dinesh et al. 2017). This is due, in large part, to the fact that intercropping has the potential to promote an efficient use of two limiting factors for plant growth, i.e. water and nutrients, by an improved acquisition of these resources through complementary root distributions, water sharing mechanisms such as hydraulic redistribution (HR), common mycorrhizal networks, and/or reduced runoff leading to increased water infiltration (Bayala and Wallace 2015; Brooker et al. 2015; Mao et al. 2012; Prieto et al. 2012b). To take advantage and promote the use of these mechanisms in agricultural systems there is a need for a careful design of the species mixtures used (Altieri et al. 2015; Dupraz et al. 1997; Malézieux et al. 2009; Ong and Leakey 1999; van Noordwijk and Ong 1999). In agroforestry systems, annual crops are typically shallow-rooted while perennial plants include trees that have root systems extending deeper in the soil giving foundation to the safety-net hypothesis (Rowe et al. 1999; van Noordwijk and van de Geijn 1996; van Noordwijk et al. 2015). The safety-net hypothesis, i.e. intercepting mobile nutrients leaching from crop root zones, is also complementary to the nutrient pump hypothesis which refers to the taking-up of nutrients, generally relatively immobile, from deep soil layers, their incorporation in aboveground plant tissues (i.e. leaves) and their transfer to upper soil layers through leaf shedding and decomposition (Ong and Leakey 1999; van Noordwijk and Ong 1999; Jobbagy and Jackson 2004). However, these mechanisms can be far more complex and dynamic (Akinnifesi et al. 2004; Brooksbank et al. 2011a; Schroth 1998; van Noordwijk et al. 2015) and depend on seasonal shifts of water availability and nutrient extraction from different soil depths (Bargués Tobella et al. 2017).

This complexity has prompted an increased interest of the scientific community in agroforestry systems that started with more descriptive work and then moved to more complex studies trying to understand the mechanisms behind resource sharing between intercropped plants and the quantification of these processes for plant growth (Black et al. 2015; van Noordwijk et al. 2004). The fast development of different tools and approaches in this field have helped researchers to investigate plant root distributions and structure in these systems for a better understanding of the interactions and processes involved belowground (Cardinael et al. 2015; Ong et al. 2014; Tracy et al. 2015). Despite these advances, root research in mixed tree-crop agroforestry systems remains challenging because of the difficulty in finding the relevant spatial and temporal scales for the high heterogeneity of soil conditions in these systems. Besides spatial differentiation of root systems between plant species, some functional traits linked to resource acquisition, including selective root placement (SRP), root length density (RLD) or specific root length (SRL), are increasingly being used to evaluate the competitiveness of plant species (e.g. acquisitive fast-growing versus conservative slow-growing strategies) for the different resources in mixed systems (Bardgett et al. 2014; Prieto et al. 2015; Ravenek et al. 2016; Reich 2014). However, to date there is no consensus on which are the most relevant traits that confer a true advantage in belowground plant competition (Ravenek et al. 2016).

Putting more efforts in these under-researched areas will be pivotal for designing the best mixtures of tree and crop species for agroforestry practices that provide beneficial outputs both for the communities and the environment (Altieri et al. 2015; Gutoa et al. 2012; Malézieux et al. 2009). Based on the key concepts of interspecific competition and facilitation between plants in link with root functional traits, this paper reviews the beneficial and adverse effects of trees and crops on water acquisition and redistribution in agroforestry ecosystems.

\section{Water acquisition by roots}

Sampling patterns to measure soil water contents in agroforestry systems vary according to the studied agroforestry practice (transect, random, etc.) but taking soil water content measurements at various distances from the plant and at different soil depths and comparing situations with agroforestry practice against monoculture practices (control) has been the most common approach (Bayala and Wallace 2015; Ong et al. 2014; Fig. 1). Measurement methods have also undergone a tremendous development from gravimetry measurements based on soil weighing to automated and remotely controlled measurements using wireless networks that allow a continuous monitoring of the soil water status (Bogena et al. 2007; Tracy et al. 2015). Even though the relationship between tree cover and water supply is not straightforward, the tree components in agroforestry practices are in general expected to reduce runoff and thus increase soil water infiltration favoring the uptake 
of water from deep soil layers by plant roots and a potential recycling of this water in upper soil layers through water redistribution (discussed in more detail in the next section). Kuyah et al. (2016) reviewed the roles of trees on agroforestry farms in semi-arid sub-Saharan Africa and found that, in most cases, trees had beneficial effects on associated crops by enhancing soil water availability in $58 \%$ of the studies considered in the their review. These correspond to situations in which a strategic placement of trees in the landscape at an optimal density induces desired positive effects on local hydrology (Brooksbank et al. 2011b; Siriri et al. 2010, 2012). For example, it has been reported that a moderate tree cover could enhance groundwater recharge (Ilstedt et al. 2016) because of increased infiltrability and higher preferential flow due to the channels left by decayed roots and an increased faunal activity (Bargués Tobella et al. 2014; Ghestem et al. 2011). In the same site, it was found that trees obtained $90 \%$ of their water from upper soil layers during the rainy season and switched to taking up $50 \%$ of their water from groundwater during the dry season (Bargués Tobella et al. 2017; Roupsard et al. 1999). That could partly explain why some tree species in drylands can flower and fruit during the dry season, but this remains an assumption that needs to be verified in future studies. Thus, this source of blue water (water from rivers, lakes and groundwater) being recycled as green water (rainwater absorbed by the plants) may be playing an important role in the overall performance of the agroecosystems in these areas. Furthermore, it has been found that an increase of tree cover beyond the optimum to maintain a stable groundwater recharge, decreased infiltration and recharge but remained at higher levels than in scenarios without any trees (Ilstedt et al. 2016). In addition, tree roots help aggregate soil particles increasing soil stability and reducing runoff and increasing water infiltration. This effect is due to tree root exudates that could explain approximately $20 \%-75 \%$ of the variation on the antierodibility of soils (AES) according to Wang et al. (2017). Exudates and decayed roots are also a source of carbon to the soil which, together with root mass densities, were reported to influence the formation of soil aggregates and increase their stability (Kalhoro et al. 2017; Le Bissonnais et al. 2018).

The roots of plants have several functions such as anchorage, storage (carbohydrates), resource acquisition (water and nutrients), and communication (cytokinins, gibberellins and other growth regulators) but most of the controlling factors of these functions are still not fully known (Hopmans and Bristow 2002; Ryan et al. 2016).
Information on the root distribution of tree species is mostly concentrated on the total root mass, that generally includes both fine $(<2 \mathrm{~mm})$ and coarse roots $(>2 \mathrm{~mm})$ while it is the finest part of the root systems (i.e. the finest roots and lower root orders) that are most dynamic and most actively involved in water and nutrient uptake and hence of greater interest in agroforestry (van Noordwijk and van de Geijn 1996; Wajja-Musukwe et al. 2008). Water uptake by the roots is triggered by a demand of this resource from the leaves creating a tension that propagates down to the roots and induces an inflow (or outflow in the case of redistribution) of water from the rhizosphere following paths of low soil hydraulic resistance (Lobet et al. 2014; McElrone et al. 2013; Steudle 2001). Thus, root uptake dynamics are usually related to root-length densities and root surface area (Lobet et al. 2014; van Noordwijk 1993), even if we do not account for the fact that uptake is also controlled by root age and other mechanisms taking place within the roots and in their surrounding rhizosphere (mucilage exuded by roots, the gradient in soil water potential around the roots, changes in hydraulic conductivities along the roots, etc., Carminati et al. 2016; Hopmans and Bristow 2002).

In agroforestry systems crops take up water mostly from the upper soil whereas trees may display a more opportunistic strategy obtaining most of its water from the upper soil during the wet season and switching to water stored deeper in the soil, e.g. groundwater, during the dry season when upper soil layers are dry (Bargués Tobella et al. 2017). Many studies have revealed that the root distribution of most tree species in agroforestry systems overlaps in the upper soil layers with the shallower root systems of associated annual plants (Schroth 1995; Smith et al. 1999). This root distribution allows accumulating a high proportion of their fine roots in upper soil layers and gives the plant access to intermittent soil moisture and soil nutrients in topsoil layers while the primary root grows deeper to facilitate extracting soil water from deeper wetter layers (Dhyani et al. 1990). Such accumulation of fine roots in the upper soil layers may generate a competition between the tree and associated annual crops for water (and nutrients) since root placement is a strategy for competitiveness (Ravenek et al. 2016). Despite this, selecting tree and crop species and provenances according to rootrelated criteria with deeper roots for agroforestry systems (Schroth 1995) is rarely done (Rowe et al. 1999; Smith et al. 1999) but a few studies have found separate niches for tree and crop absorptive root systems in response to agricultural practices with tree roots developing below the 
Fig. 1 Current knowledge on water acquisition and sharing and their potential applications in agroforestry systems
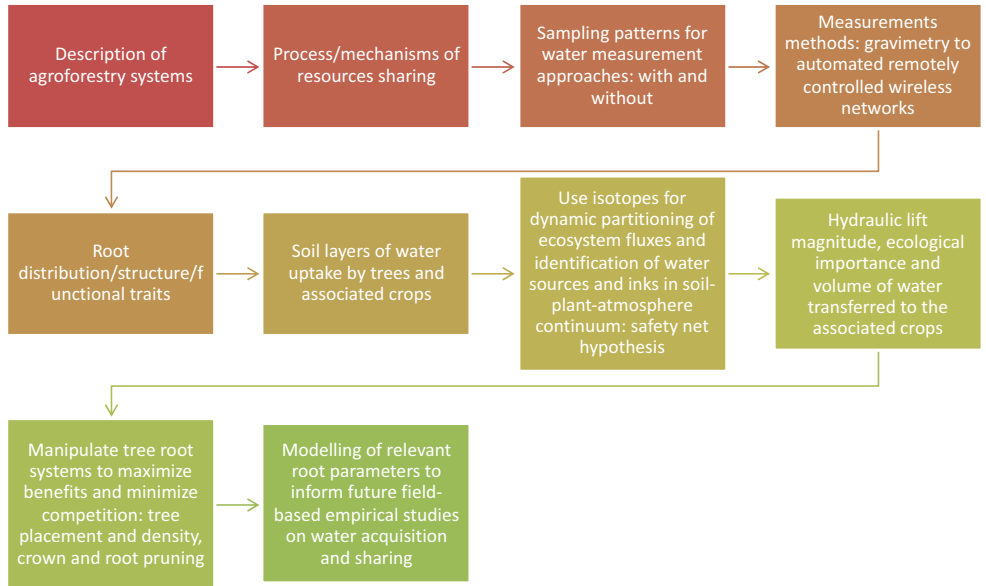

crop rooting depth (Akinnifesi et al. 1999; Dupraz et al. 2005; Howard et al. 1997; Rowe et al. 1999; Ruhigwa et al. 1992; Singh 1994). A good option may therefore be to manipulate tree root systems to maximize benefit while minimizing competition with crop species (Bayala et al. 2013; Cardinael et al. 2015; Hou et al. 2003; Siriri et al. 2013), which implies reducing niche overlap by limiting tree root growth in the crop rooting zone (Bayala et al. 2013; Namirembe 1999). Tree pruning has been demonstrated to reduce root growth in shallow layers but requires tedious work and labor and is not a desirable practice for carbon sequestration and nutrient cycling (Schroth 1995; Smith et al. 1999; Wajja-Musukwe et al. 2008). Another possibility would be to manipulate the tree crown because roots do not act as simple pumps and their activity is regulated by the demand in the aboveground parts of the plant (Jeschke and Hartung 2000; Jones et al. 1998). For instance, Kizito et al. (2012) showed that a partial coppice of the canopy of Guiera senegalensis reduced daytime sap-flow rates, i.e. plant transpiration. Plant water uptake is determined by a combination of soil water availability and potential transpiration by the canopy (Hoad et al. 2001). There is emerging evidence pointing to crown pruning as an effective tool to manipulate tree root dynamics of shallow-rooted tree species (Bayala et al. 2002, 2004; Bazié et al. 2012; Jackson et al. 2000; Jones et al. 1998; Siriri et al. 2013). All these studies revealed a decrease in tree root densities in shallow soil because of the forced reduction of the tree aboveground demand. Indeed, Jones et al. (1998) observed a marked reduction in root length densities of Prosopis juliflora trees 60 days after pruning, a reduction that was more pronounced in upper soil layers. This reduced competition from tree roots in shallow soil layers allowed for a better development of crop roots and associated sorghum plants developed higher root densities under pruned $P$. juliflora trees even though this occurred only in the uppermost shallow layers (10-20 cm depth). Another effect of tree crown pruning is that a reduction or removal of the tree crown will lead to an increase in soil temperature and a reduction of soil water in the upper soil layers around the tree (Bayala et al. 2004) that will affect fine root growth and development since fine roots are highly sensitive to changes in soil temperature and moisture. Because root functioning is also under the control of aboveground parts of the plant (Friend et al. 1990; Hoad et al. 2001; Jeschke and Hartung 2000; Steudle 2000), crown reduction will also lead to a decrease in water and nutrient demand and consequently a reduction of fine roots in shallow soil layers. Water and to some extent nutrients are the most limiting factors in semiarid areas. If, because of crown pruning, less water and nutrients are taken up by trees from the topsoil layer, this means greater availability of these resources for the associated crops, at least in the short term. Consequently, this may lead to more space for crop roots and thus higher crop root density and ultimately to better crop production under pruned trees (Bayala et al. 2004). A decrease in the production of tree fine roots in upper soil layers and their increase in deeper soil layers may not only reduce tree/ crop competition and improve crop production but also help improve the benefits of the "safety-net" hypothesis described by Cadisch et al. (1997), Rowe et al. (1999) and Vanlauwe et al. (2002). This hypothesis postulates that deep rooting trees can utilize more efficiently leached 
nutrients beyond the range of crop roots when the demand for these nutrients is high (Cadisch et al. 1997; Gathumbi et al. 2002; Lehmann et al. 1998a, b; Suprayogo et al. 2002). A high safety-net efficiency requires a minimal tree RLD to a certain depth, a minimal level of activity of tree roots present in the soil layers considered, and a minimal demand by the tree for the nutrient considered (Cadisch et al. 1997; Vanlauwe et al. 2002).

Thus, pruning has been shown to reduce root biomass and this was ascribed to translocation of carbohydrates from roots to shoots to maintain their growth and the functional equilibrium between the two compartments (Govindrajan et al. 1996; Hoad et al. 2001; Namirembe 1999). Nevertheless, the impact of pruning is variable and depends on the species considered (Akinnifesi et al. 1999; Jones et al. 1998; Odhiambo et al. 2001; Schroth and Lehmann 1995), on management practices (Govindrajan et al. 1996; Namirembe 1999) and on environmental conditions (Vanlauwe et al. 2002; Vogt et al. 1998). The distribution of plant roots within soil layers is also a dynamic process disagreeing with Jones et al. (1998) and Smith et al. (1999) who found that tree roots dominated agroforestry plots all year-round. Indeed, Odhiambo et al. (2001) reported that tree roots were only the most abundant about half of the cropping period. In some circumstances, pruning induces no effect on tree roots and may even increase root production (van Noordwijk and Purnomosidhi 1995). In any case, the effect of tree pruning and root reductions on well-established trees is transient and needs to be repeated in subsequent periods since root growth and production will recover as the tree crown regains its size (Bayala et al. 2004; Namirembe 1999; Odhiambo et al. 2001).

\section{Water sharing and redistribution by roots}

In addition to improving soil conditions for enhanced water infiltration and storage, trees reduce solar radiation underneath leading to lower evapotranspiration and greater soil water contents under their canopies. Another process leading to increased soil water content in the upper rooting zone under trees is the process of hydraulic lift (HL) or water redistribution by roots, which is defined as the passive movement of water through the roots of trees, from deeper and wetter soil layers to shallower and drier horizons, along a gradient of soil water potential (Richards and Caldwell 1987). The HL process usually occurs during the night when plant transpiration is low or null (Prieto et al. 2010b; Hultine et al. 2003) and the water potential gradient is established between wetter and drier soil layers, but has been reported to occur during the day under particular soil conditions, e.g. along water potential gradients created by variations in soil salinity (Hao et al. 2009). Although the direction of water movement is typically upward, towards drier, shallow soil layers, measurements of sap flow in taproots and lateral roots of trees have demonstrated that roots can also redistribute water downward or laterally from moist surface soils to drier regions of soil (Burgess et al. 1998; Hultine et al. 2003; Nadezhdina et al. 2006). This bidirectional movement of water was termed "hydraulic redistribution (HR, Burgess et al. 1998). The process of HL is generally found in species with dimorphic root systems with access to water from both shallow and deep soil layers (Scholz et al. 2008). Hydraulic lift has been shown to be ubiquitous as long as conditions favors its occurrence and has been reported in a large number of species from various climates including Mediterranean ecosystems, cool temperate regions and seasonally dry tropical and subtropical habitats (Horton and Hart 1998; Jackson et al. 2000; Neumann and Cardon 2012; Prieto et al. 2012b). One important aspect is that HL has also been described in many woody species widely used in agroforestry systems such as Azadirachta indica, Acacia tortilis, Eucalyptus kochii subsp. borealis, Guiera senegalensis, Parkia biglobosa, Piliostigma reticulatum, Vitellaria paradoxa(Bayala et al. 2008; Brooksbank et al. 2011a; Kizito et al. 2006, 2012; Ludwig et al. 2003; Smith et al. 1997).

The ecological or agroecological relevance of HR both to the plant engaged in HR and for neighboring plants has been widely reported by many authors (see reviews by Burgess 2011; Caldwell et al. 1998; Liste and White 2008; Neumann and Cardon 2012; Prieto et al. 2012b). For the plant, HR can improve plant transpiration rates and plant water status (Dawson and Pate 1996); reported estimates of the total volume of water lifted range from $5 \%$ to $30 \%$ of the total plant transpiration suggesting that hydraulic redistribution 
could postpone the development of water stress and mitigate the impact of soil drying in the surface horizons (Caldwell et al. 1998; Emerman and Dawson 1996; Oliveira et al. 2005; Warren et al. 2005, 2007). Hydraulic lift has other side benefits such as higher fine root survival (Bauerle et al. 2008), a limited root embolism during the day by refilling xylem conduits at night (Domec et al. 2004, 2006; Prieto and Ryel 2014) or improved soil nutrient recycling that could benefit both the woody species and associated crops (Aanderud and Richards 2009; Armas et al. 2012; Cardon and Gage 2006; Cardon et al. 2013; Prieto et al. 2012a). For neighboring plants, water that is redistributed to shallow soil layers can also be taken up by plants living in close association to plants engaged in HL enhancing their transpiration and ultimately increasing their survival and biomass production (Bogie et al. 2018; Izumi et al. 2018; Lee et al. 2018; Prieto et al. 2011). Nevertheless, the net effects that species engaged in HR have on their neighbors is still unclear (Prieto et al. 2012b). There are reports of positive, neutral or even negative effects depending on ecosystem type, plant life form or whether donor and receiver species shared common ecto- and endomycorrhizal networks. We need to note here that common mycorrhizal networks are strongly involved in water and nutrient sharing between plant species (Allen 2007; Montesinos-Navarro et al. 2019) and play an important role in the transfer of lifted water between species and within individuals of the same species (Querejeta et al. 2003, 2012; Egerton-Warburton et al. 2007; Prieto et al. 2016; Warren et al. 2008). However, our knowledge on the importance of mycorrhizal pathways in agroforestry systems is still very limited (de Carvalho et al. 2010) and will not be discussed in this review but opens up new areas of research to differentiate between root-only- and root-mycorrhizal-based transfer of HL water (Fig. 2). Several studies have shown that HL enhances water availability to plants (McMichael and Lascano 2010; Hirota et al. 2004; Prieto et al. 2011; Shen et al. 2011; Smart et al. 2005; Wan et al. 2000), thereby promoting microbial processes and decomposition processes which release nutrients from organic matter and soil minerals (Aanderud and Richards 2009; Armas et al. 2012; Austin et al. 2004; Cardon et al. 2013; Matimati et al. 2014; Munoz et al. 2008; Prieto et al. 2012a; Smith et al. 1999; Yoder and Nowak 1999) that could also benefit the growth and survival of plant neighbors. The process of HL may therefore contribute significantly towards meeting the water, and or nutrient supplies needed to support growth and grain filling in associated crops in agroforestry systems with limited water availability (Bogie et al. 2018; Izumi et al. 2018). The potential application and exploitation of HL to improve water availability to crops or seedlings/saplings in forestry and ecological restoration has been already suggested (Burgess 2011; Liste and White 2008) but, to date, real-world experimental tests in agroforestry systems are still limited but show promising results. For example, Kizito et al. (2012) estimated that, in two species commonly used in agroforestry (Guiera senegalensis and Piliostigma reticulatum), HL alone could account for up to 35$47 \mathrm{~mm}$ of water annually, which represents between $8 \%$ and $10 \%$ of the mean annual precipitation $(450 \mathrm{~mm})$ in the Sahel. Under similar environmental conditions, Vadez et al. (2013) showed that pearl millet (Penissetum glaucum) yield could increase by up to 3.5$4.7 \mathrm{~g}$ per plant for each additional $\mathrm{mm}$ of water provided, which means that, in regular planting densities of 10,000 plants $\mathrm{ha}^{-1}$, the additional water provided through HL could result in substantial yield increases of $35-47 \mathrm{~kg} \mathrm{ha}^{-1} \mathrm{~mm}^{-1}$. Experimental evidence of such increases in plant crop biomass when grown in association with species engaged in HL was reported in a subsequent study by Bogie et al. (2018). These authors used an enriched deuterium $\left({ }^{2} \mathrm{H}\right)$ water tracer to demonstrate that the associated pearl millet crop took up water that had been lifted by the shrubs. They concluded that, along with other potential beneficial factors of growing crops in association with the shrubs (shade or lower temperatures), HL contributed largely to the $900 \%$ increase in pearl millet biomass from below $200 \mathrm{~kg} \mathrm{ha}^{-1}$ in the control. In addition to the extra water provided by HL, crops could also benefit from other side benefits of improved soil moisture conditions such as a faster nutrient recycling and uptake under plants engaged in HL (Sun et al. 2014). Also, competition for water between crops and associated species has been observed in agroforestry systems when tree root systems had no access to groundwater (Rao et al. 1998; Dupraz et al. 2005) and a requirement for species selection is that facilitative species have deep roots and access to deep water, or they will probably otherwise outcompete crops for a limited water supply (BarronGafford et al. 2017; Van Noordwijk and Ong 1999). Thus, the relative importance of complementarity for water via HR or competition may therefore depend on particular soil conditions such as soil moisture content, as well as other factors known to shape inter-plant interactions (Bayala 
et al. 2008; Hirota et al. 2004; Ludwig et al. 2003, 2004). These reported benefits for plant production and survival, however, may be thus largely dependent on the context and the species involved (Prieto et al. 2012b), which may be particularly true in mixed agroforestry systems where shading and micro-climatic effects could have an equally important influence on plant growth and survival (Prieto et al. 2011).

One interesting aspect of the use of HR in agroforestry systems is promoting positive plant interactions by an active management of agroforestry systems. One example of such management was provided by Sekiya et al. (2011) that grew a crop in association to deeprooted forage plants in an agricultural field. To remove competition for water and promote the uplift of water from deep soil layers, they removed the shoots of deeprooted plants forcing HL $24 \mathrm{~h}$ a day, which resulted in a better crop water status and greater biomass production. As these shoot-less plants were found to be effective bio-irrigators, the mechanism at play could be HL until root death and a capillary or "wick" effect afterwards (Leffler et al. 2005). This calls for a better understanding of the fundamentals of HL before we can apply effective bio-irrigation techniques such as total plant removal.
Although this example has not been replicated since, common agricultural practices in agroforestry systems that do not completely remove the canopy, such as tree pruning or shading, can be tested as effective mechanisms favoring the process of HL since reducing aboveground canopy transpiration can enhance the amount of water lifted to topsoil layers (Prieto et al. 2010a, b; Sekiya and Yano 2004). Furthermore, the remnants from cutting the shoots of deep-rooted forage plants can be recycled into forage for animals providing an additional benefit for such systems. Therefore, a directed selection of pairs of species in intercropped systems along with agricultural practices, may help overcome this problem and promote water sharing between the tree and neighboring crops and the use of HR as a bioirrigation system. However, our knowledge in the incorporation of species engaged in HL in agroforestry systems is still very limited and further efforts in applied research are still needed to assess which species would be better suited to be used as "bioirrigators", in which context or environments, the magnitude of the volumes effectively transferred to the associated crops/plants and what crops would benefit more from this lifted water along with its impact on plant productivity (Fig. 2).

\section{Future directions in $\mathrm{AF}$ research}

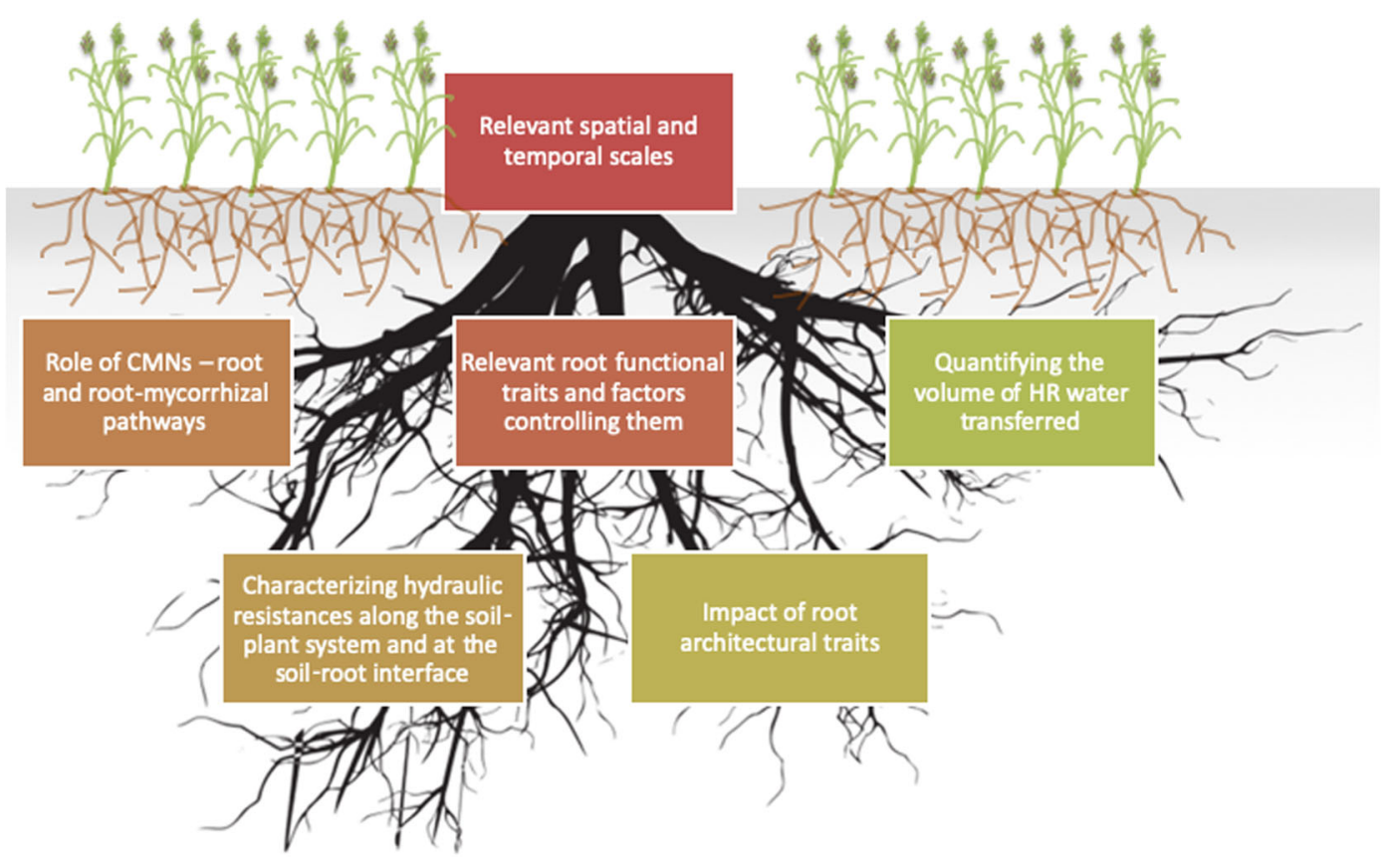

Fig. 2 Future investigation areas for water acquisition and sharing in agroforestry systems 


\section{Conclusion}

This review provides an overview of our current knowledge on water acquisition and sharing mechanisms in agroforestry systems. Based on key concepts such as interspecific competition and facilitation through water transfer between plants, this paper reviews water acquisition and redistribution patterns and their potential application in agroforestry ecosystems. In promoting agroforestry as an ecologically adapted farming system for addressing environmental issues caused by intensive monoculture, the central assumption that underpinned the science and practice is that trees take up water from deep soil layers and recycle it in upper soil layers through water redistribution, thus making it available to nearby shallow rooted associated crops. Therefore, research actions have covered a range of topics including safety net hypothesis, root distribution, root functional traits, HL/redistribution and its ecological importance, hydraulically water lifted transfer between species, water source using isotopes, and modelling of relevant root parameters to inform future field-based empirical studies on water acquisition and sharing. In this sense, a better characterization of the hydraulic resistances of the soil-plant system, particularly at the soil-root interface in one hand and in another hand a better characterization of the soil system and hydraulic architectures are pivotal to improving our quantitative understanding of HL (Meunier et al. 2017). Despite clear advances, root research in mixed tree-crop agroforestry systems remains challenging because of the difficulty in finding the relevant spatial and temporal scales as well as a lack of consensus about the most relevant traits that confer a true advantage in belowground plant competition. Other under-researched areas which equally deserve more attention to be able to design the best mixtures of tree and crop species for agroforestry practices that provide beneficial outputs both for the communities and the environment include (Fig. 2):

- Investigating and determining the controlling factors of the root functional traits;

- Clarifying and quantifying the role of common mycorrhizal networks in the mechanism of HL, including the proportion of water transferred through root-only- and root-mycorrhizal-based HL, and their importance and applications in agroforestry systems;
- Characterizing hydraulic resistances along the soilplant system, particularly at the soil-root interface, and root hydraulic architectures to gain knowledge on the potential for water uptake and water transfer patterns in agroforestry systems;

- Quantifying the volume of water transferred to neighboring plants through HL and their species and environment, including soil type and dependence;

- Disentangling the advantages and potentially adverse effects of hydraulically redistributed water (e.g. in saline systems).

Acknowledgements JB was supported by the Livelihood Systems flagship of the CGIAR research program on Forests, Trees and Agroforestry (FTA) and IP acknowledges funding from the Juan de la Cierva program (FPDI-2013-16221) and the Spanish Ministerio de Economía y Competitividad (project CGL201348753-R). The anonymous reviewers are highly appreciated and thanked for their constructive comments.

Open Access This article is distributed under the terms of the Creative Commons Attribution 4.0 International License (http:// creativecommons.org/licenses/by/4.0/), which permits unrestricted use, distribution, and reproduction in any medium, provided you give appropriate credit to the original author(s) and the source, provide a link to the Creative Commons license, and indicate if changes were made.

\section{References}

Aanderud ZT, Richards JH (2009) Hydraulic redistribution may stimulate decomposition. Biogeochemistry 95:323-333

Akinnifesi FK, Knag BT, Ladipo DO (1999) Structural root form and fine root distribution of some woody species evaluated for agroforestry systems. Agrofor Syst 42:121-138

Akinnifesi F, Rowe E, Livesley S, Kwesiga F, Vanlauwe B, Alegre J, van Noordwijk M, Cadisch G, Ong C (2004) Tree root architecture. Below-ground interactions in tropical. In: van Noordwijk M, Cadisch G, Ong CK (eds)Below-ground Interactions in Tropical Agroecosystems: Concepts and Models with Multiple Plant Components. CAB International, Wallingford, pp 61-81

Allen MF (2007) Mycorrhizal Fungi: Highways for Water and Nutrients in Arid Soils. Vadose Zo J 6:291-297

Altieri MA, Nicholls CI, Henao A, Lana MA (2015) Agroecology and the design of climate change-resilient farming systems. Agron Sustain Dev 35:869-890

Armas C, Kim JH, Bleby TM, Jackson RB (2012) The effect of hydraulic lift on organic matter decomposition, soil nitrogen cycling, and nitrogen acquisition by a grass species. Oecologia 168:11-22 
Austin AT, Yahdjian L, Stark JM, Belnap J, Porporato A, Norton U, Ravetta DA, Schaeffer SM (2004) Water pulses and biogeochemical cycles in arid and semiarid ecosystems. Oecologia 141:221-235

Bardgett RD, Mommer L, de Vries FT (2014) Going underground root traits as drivers of ecosystem processes. Trends Ecol Evol 29:692-699

Bargués Tobella A, Reese H, Almaw A, Bayala J, Malmer A, Laudon H, Ilstedt U (2014) The effect of trees on preferential flow and soil infiltrability in an agroforestry parkland in semiarid Burkina Faso. Water Resour Res 50:3342-3354

Bargués Tobella A, Hasselquist NJ, Bazié HR, Nyberg G, Laudon H, Bayala J, Ilstedt U (2017) Strategies trees use to overcome seasonal water limitation in an agroforestry system in semiarid West Africa. Ecohydrology. 10:e1808. https://doi. org/10.1002/eco.1808

Barron-Gafford GA, Sanchez-Cañete EP, Minor RL, Hendryx SM, Lee E, Sutter LF, Tran N, Parra E, Colella T, Murphy PC, Hamerlynck EP, Kumar P, Scott RL (2017) Impacts of hydraulic redistribution on grass-tree competition vs facilitation in a semi-arid savanna. New Phytol 215(4): 1451-1461

Bauerle TL, Richards JH, Smart DR, Eissenstat DM (2008) Importance of internal hydraulic redistribution for prolonging the lifespan of roots in dry soil. Plant Cell Environ 31:177-186

Bayala J, Wallace JW (2015) The water balance of mixed tree-crop systems. In: Black C., Wilson J, Ong CK (eds.), Tree-Crop Interaction: Agroforestry in a Changing Climate. CABI, London, pp 146-190

Bayala J, Teklehaimanot Z, Ouedraogo SJ (2002) Millet production under pruned tree crowns in a parkland system in Burkina Faso. Agrofor Syst 54:203-214

Bayala J, Teklehaimanot Z, Ouedraogo SJ (2004) Fine root distribution of pruned trees and associated crops in a parkland system in Burkina Faso. Agrofor Syst 60:13-26

Bayala J, Heng LK, van Noordwijk M, Ouedraogo SJ (2008) Hydraulic lift study in two native tree species of agroforestry parklands of West African dry savanna. Acta Oecol 34:370 378. https://doi.org/10.1016/j.actao.2008.06.010

Bayala J, Bazié HR, Sanou J (2013) Competition and facilitationrelated factors impacts on crop performance in an agroforestry parkland system in Burkina Faso. Afr J Agric Res 8(43):53035310

Bazié HR, Bayala J, Zombré G, Sanou J, Ilstedt U (2012) Separating competition-related factors limiting crop performance in an agroforestry parkland system in Burkina Faso. Agrofor Syst 84:377-388

Black C, Randhawa D, Ong CK (2015) Principles of resource capture and use of light and water. In: Black C, Wilson J, Ong CK (eds.), Tree-Crop Interactions: Agroforestry in a Changing Climate, CABI, London, pp. 57-118

Bogena HR, Huisman JA, Oberdörster C, Vereecken H (2007) Evaluation of a low-cost soil water content sensor for wireless network applications. J Hydrol 344:32-42

Bogie NA, Bayala R, Diedhiou I, Conklin MH, Fogel ML, Dick RP, Ghezzehei TA (2018) Hydraulic Redistribution by Native Sahelian Shrubs: Bioirrigation to Resist In-Season Drought. Front Environ Sci 6, Article 98. https://doi. org/10.3389/fenvs.2018.00098

Brooker RW, Bennett AE, Cong W-F et al (2015) Improving intercropping: a synthesis of research in agronomy, plant physiology and ecology. New Phytol 206:107-117
Brooksbank K, Veneklaas EJ, White DA, Carter JL (2011a) The fate of hydraulically redistributed water in a semi-arid zone eucalyptus species. Tree Physiol 31:649-658

Brooksbank K, Veneklaas EJ, White DA, Carter JL (2011b) Water availability determines hydrological impact of tree belts in dryland cropping systems. Agric Water Manag 100(1):76-83

Burgess SSO (2011) Can hydraulic redistribution put bread on our table? Plant Soil 341:25-29

Burgess SSO, Adams MA, Turner NC, Ong CK (1998) The redistribution of soil water by tree root systems. Oecologia 115:306-311

Cadisch G, Rowe E, van Noordwijk M (1997) Nutrient harvesting - the tree-root safety net. Agroforestry Forum 8(2):31-33

Caldwell MM, Dawson TE, Richards JH (1998) Hydraulic lift: consequences of water efflux for roots of plants. Oecologia 113:151-161

Cardinael R, Mao Z, Prieto I, Stokes A, Dupraz C, Kim J, Jourdan C (2015) Competition with winter crops induces deeper rooting of walnut trees in a Mediterranean alley cropping agroforestry system. Plant Soil 391:219-235

Cardon ZG, Gage DJ (2006) Resource exchange in the rhizosphere: molecular tools and the microbial perspective. Annu Rev Ecol Evol Syst 37:459-488

Cardon ZG, Stark JM, Herron PM, Rasmussen JA (2013) Sagebrush carrying out hydraulic lift enhances surface soil nitrogen cycling and nitrogen uptake into inflorescences. Proc Natl Acad Sci U S A 110:18988-18993

Carminati A, Zarebanadkouki M, Kroener E, Ahmed MA, Holz M (2016) Biophysical rhizosphere processes affecting root water uptake. Ann Bot 118:561-571

Dawson TE, Pate JS (1996) Seasonal water uptake and movement in root systems of Australian phraeatophytic plants of dimorphic root morphology: a stable isotope investigation. Oecologia 107:13-20

de Carvalho AMX, de Castro Tavares R, Cardoso IM, Kuyper TW (2010) Mycorrhizal Associations in Agroforestry Systems. In: Dion P (ed) Soil Biology and Agriculture in the Tropics, Soil Biology 21. Springer-Verlag, Berlin, pp 185-208

Dhyani SK, Narain P, Singh RK (1990) Studies on root distribution of five multipurpose tree species in Doon Valley, India. Agrofor Syst 12:149-161

Dinesh D, Campbell B, Bonilla-Findji O, Richards M (2017) 10 best bet innovations for adaptation in agriculture: A supplement to the UNFCCC NAP Technical Guidelines. CCAFS Working Paper no. 215. Wageningen, The Netherlands: CGIAR Research Program on Climate Change, Agriculture and Food Security (CCAFS)

Domec JC, Warren JM, Meinzer FC, Brooks JR, Coulombe R (2004) Native root xylem embolism and stomatal closure in stands of Douglas-fir and ponderosa pine: mitigation by hydraulic redistribution. Oecologia 141:7-16

Domec JC, Scholz FG, Bucci SJ, Meinzer FC, Goldstein G, Villalobos Vega R (2006) Diurnal and seasonal variation in root xylem embolism in neotropical savanna woody species: impact on stomatal control of plant water status. Plant Cell Environ 28:1634-1643

Dupraz C, Newman SM, Gordon AM (1997) Temperate agroforestry: the European way. In: Gordon AM, Newman SM (eds) Temperate agroforestry systems. CAB International, Wallingford, pp 181-236 
Dupraz C, Burgess P, Gavaland A, Graves A, Herzog F, Incoll L, van der Werf W et al (2005) Synthesis of the silvoarable agroforestry for Europe (SAFE) project, INRA-UMR System Editions, Montpellier, p 254

Egerton-Warburton LM, Querejeta JI, Allen MF (2007) Common mycorrhizal networks provide a potential pathway for the transfer of hydraulically lifted water between plants. J Exp Bot 58:1473-1483

Emerman SH, Dawson TE (1996) Hydraulic lift and its influence on water content of the rhizosphere an example from sugar maple, Acer saccharum. Oecologia 108:273-278

Friend AL, Eide MR, Hinekley TM (1990) Nitrogen stress alters root proliferation in Douglas-fir seedlings. Can J For Res 20: 1524-1529

Gathumbi SM, Ndufa JK, Giller KE, Cadisch G (2002) Do species mixtures increase above- and belowground resource capture in woody and herbaceous tropical legumes? Agron J 94:518-526

Ghestem M, Sidle RC, Stokes A (2011) The influence of plant root systems on subsurface flow: implications for slope stability. BioScience 61:869-879

Govindrajan M, Rao MR, Mathuva MN, Nair PKR (1996)Soilwater and root dynamics under hedgerow intercropping in semiarid Kenya. Agron J 88:513-520

Gutoa SN, de Ridder N, Giller KE, Pypers P, Vanlauwe B (2012) Minimum tillage and vegetative barrier effects on crop yields in relation to soil water content in the Central Kenya highlands. Field Crop Res 132:129-138

Hao GY, Jones TJ, Luton C et al (2009) Hydraulic redistribution in dwarf Rhizophora mangle trees driven by interstitial soil water salinity gradients: impacts on hydraulic architercture and gas exchange. Tree Physiol 29:697-705

Hirota I, Sakuratani T, Sato T, Higuchi H, Nawata E (2004) A split-root apparatus for examining the effects of hydraulic lift by trees on the water status of neighbouring crops. Agrofor Syst 60:181-187

Hoad SP, Russell G, Lucas ME, Bingham IJ (2001) The management of wheat, barley, and oat root systems. Adv Agron 74:193-247

Hopmans JW, Bristow K (2002) Current capabilities and future needs for root water and nutrient uptake modeling. Adv Agron 77:103-183

Horton JL, Hart SC (1998) Hydraulic lift a potentially important ecosystem process. Trends Ecol Evol 13:232-235

Hou Q, Brandle J, Hubbard K, Schoeneberger M, Nieto C, Francis C (2003) Alteration of soil water content consequent to rootpruning at a windbreak/crop interface in Nebraska, USA. Agrofor Syst 57:137-147

Howard SB, Ong CK, Black CR, Khan AAH (1997) Using sap flow gauges to quantify water uptake by tree roots from beneath the crop rooting zone in agroforestry. Agrofor Syst 35:15-29

Hultine KR, Williams DG, Burgess SSO, Keefer TO (2003) Contrasting patterns of hydraulic redistribution in three desert phreatophytes. Oecologia 135:167-175

Ilstedt U, Bargués Tobella A, Bazié HR, Bayala J, Verbeeten E, Nyberg G, Sanou J, Benegas L, Murdiyarso D, Laudon H, Sheil D, Malmer A (2016) Intermediate tree cover can maximize groundwater recharge in the seasonally dry tropics. Sci Rep 6:21930. https://doi.org/10.1038/srep21930

Izumi Y, Okaichi S, Awala SK et al (2018) Water supply from pearl millet by hydraulic lift can mitigate drought stress and improve productivity of rice by the close mixed planting. Plant Prod Sci 21:8-15
Jackson NA, Wallace JS, Ong CK (2000) Tree pruning as a means of controlling water use in an agroforestry system in Kenya. Forest Ecol Manag 126:133-148

Jeschke WD, Hartung W (2000)Root-shoot interactions in mineral nutrition. Plant Soil 226:57-69

Jobbagy EG, Jackson RB (2004) The uplift of soil nutrients by plants: biogeochemical consequences across scales. Ecology 85:2380-2389

Jones M, Sinclair FL, Grime VL (1998) Effects of tree species and crown pruning on root length and soil water content in semiarid agroforestry. Plant Soil 201:197-207

Kalhoro SA, Xu X, Chen W, Hua R, Raza S, Ding K (2017) Effects of different land-use systems on soil aggregates: a case study of the loess plateau (northern china). Sustainability 9:1349. https://doi.org/10.3390/su9081349

Kizito F, Dragila M, Sène M, Lufafa A, Diedhiou I, Dick RP, Selker JS, Dossa E, Khouma M, Badiane A, Samba SAN (2006) Seasonal soil water variation and root patterns between two semi-arid shrubs co-existing with Pearl millet in Senegal, West Africa. J Arid Environ 67:436-455

Kizito F, Dragila MI, Senè M, Brooks JR, Meinzer FC, Diedhiou I, Diouf M, Lufafa A, Dick RP, Selker J, Cuenca R (2012) Hydraulic redistribution by two semi-arid shrub species: implications for Sahelian agro-ecosystems. J Arid Environ 83:69-77

Kuyah S, Öborn I, Jonsson M, Dahlin SA, Barrios E, Muthuri C, Malmer A, Nyaga J, Magaju C, Namirembe S, Nyberg Y, Sinclair FL (2016) Trees in agricultural landscapes enhance provision of ecosystem services in Sub-Saharan Africa. Int J Biodivers Sci Ecosyst Serv Manag 12(4):255-273

Le Bissonnais Y, Prieto I, Roumet C et al (2018) Soil aggregate stability in Mediterranean and tropical agro-ecosystems: effect of plant roots and soil characteristics. Plant Soil 424: 303-317

Lee E, Kumar P, Barron-Gafford GA, Hendryx SM, SanchezCañete EP, Minor RL, Colella T, Scott RL (2018) Impact of hydraulic redistribution on multispecies vegetation water use in a semiarid savanna ecosystem: an experimental and modeling synthesis. Water Resour Res 54:4009-4027

Leffler AJ, Peek MS, Ryel RJ et al (2005) Hydraulic redistribution through the root systems of senesced plants. Ecology 86 : 633-642

Lehmann J, Droppelmann K, Zech W (1998a) Runoff irrigation of crops with contrasting root and shoot development in northern Kenya: water depletion and above- and below-ground biomass production. J Arid Environ 38:479-492

Lehmann J, Peter I, Steglich C, Gebauer G, Huwe B, Zech W (1998b)Below-ground interactions in dryland agroforestry. Forest Ecol Manag 111:157-169

Liste HH, White J (2008) Plant hydraulic lift of soil water: implications for crop production and land restoration. Plant Soil 313:1-17

Lobet G, Couvreur V, Meunier F, Javaux M, Draye X (2014) Plant water uptake in drying soils. Plant Physiol 164:1619-1627

Ludwig F, Dawson TE, Kroon H, Brendse F, Prins HHT (2003) Hydraulic lift in Acacia tortilis trees on an east African savanna. Oecologia 134:293-300

Ludwig F, Dawson TE, Prins HHT, Berendse F, De Kroon H (2004)Below-ground competition between trees and grasses may overwhelm the facilitative effects of hydraulic lift. Ecol Lett 7:623-631 
Machado S (2009) Does intercropping have a role in modern agriculture? J Soil Water Conserv 64(2):55A-57A

Malézieux E, Crozat Y, Dupraz C, Laurans M, Makowski D, Ozier-Lafontaine H, Rapidel B, de Tourdonnet S, ValantinMorison M (2009) Mixing plant species in cropping systems: concepts, tools and models. A review. Agron Sustain Dev 29: $43-62$

Mao LL, Zhang LZ, Li WQ, van der Werf W, Sun JH, Spiertz H, Li L (2012) Yield advantage and water saving in maize/pea intercrop. Field Crop Res 138:11-20

Matimati I, Anthony Verboom G, Cramer MD (2014) Do hydraulic redistribution and nocturnal transpiration facilitate nutrient acquisition in Aspalathus linearis? Oecologia 175:1129-1142

McElrone AJ, Choat B, Gambetta GA, Brodersen CR (2013) Water uptake and transport in vascular plants. Nature Educ Knowledge 4(5):6

McMichael BI, Lascano RJ (2010) Evaluation of hydraulic lift in cotton (Gossypium hirsutum L.) germplasm. Environ Exp Bot 68:26-30

Meunier F, Draye X, Vanderborght J, Javaux M, Couvreur V (2017) A hybrid analytical-numerical method for solving water flow equations in root hydraulic architectures. Appl Math Model 52:648-663

Montesinos-Navarro A, Valiente-Banuet A, Verdú M (2019) Mycorrhizal simbiosis increases the benefits of plant facilitative interactions. Ecography 42:447-455

Munoz MR, Squeo FA, Leon MF, Tracol Y, Gutiérrez JR (2008) Hydraulic lift in three shrub species from the Chilean coastal desert. J Arid Environ 72:624-632

Nadezhdina N, Cermak J, Gasparek J et al (2006) Vertical and horizontal water redistribution in Norway Spruce (Picea abies) roots in the Moravian upland. Tree Physiol 26:1277-1288

Namirembe S (1999) Tree shoot pruning to control competition for below-ground resources in agroforestry. $\mathrm{PhD}$ thesis, School of Agricultural and Forest Sciences. University of Wales, Bangor, UK

Neumann RB, Cardon ZG (2012) The magnitude of hydraulic redistribution by plant roots: a review and synthesis of empirical and modeling studies. New Phytol 194:337-352

Odhiambo HO, Ong CK, Douglas JD, Wilson J, Khan AAH, Sprent JI (2001) Roots, soil water and crop yield: tree crop interactions in a semi-arid agroforestry system in Kenya. Plant Soil 235:221-233

Oliveira RS, Dawson TE, Burgess SSO, Nepstad DC (2005) Hydraulic redistribution in three Amazonian trees. Oecologia 145:354-363

Ong CK, Leakey RRB (1999) Why tree-crop interactions in agroforestry appear at odds with tree-grass interactions in tropical savannahs. Agrofor Syst 45:109-129

Ong C, Black CR, Wilson J, Muthuri C, Bayala J, Jackson NA (2014) Agroforestry: Hydrological Impacts. In: Van Neal A (ed) Encyclopedia of Agriculture and Food Systems, vol 1. Elsevier, San Diego, pp 244-252

Prieto I, Ryel RJ (2014) Internal hydraulic redistribution prevents the loss of root conductivity during drought. Tree Physiol 34:39-48

Prieto I, Kikvidze Z, Pugnaire FI (2010a) Hydraulic lift: soil processes and transpiration in the Mediterranean leguminous shrub Retama sphaerocarpa (L.) Boiss. Plant Soil 329:447-456

Prieto I, Martínez-Tillería K, Martínez-Manchego L et al (2010b) Hydraulic lift through transpiration suppression in shrubs from two arid ecosystems: patterns and control mechanisms. Oecologia 163:855-865

Prieto I, Padilla FM, Armas C, Pugnaire FI (2011) The role of hydraulic lift on seedling establishment under a nurse plant species in a semi-arid environment. Perspect Plant Ecol Evol Syst 13:181-187

Prieto I, Armas C, Pugnaire FI (2012a) Hydraulic lift promotes selective root foraging in nutrient-rich soil patches. Funct Plant Biol 39:804-812

Prieto I, Armas C, Pugnaire FI (2012b) Water release through plant roots: new insights into its consequences at the plant and ecosystem level. New Phytol 193:830-841

Prieto I, Roumet C, Cardinael R et al (2015) Root functional parameters along a land-use gradient: evidence of a community-level economics spectrum. J Ecol 103:361-373

Prieto I, Roldán A, Huygens D et al (2016)Species-specific roles of ectomycorrhizal fungi in facilitating interplant transfer of hydraulically redistributed water between Pinus halepensis saplings and seedlings. Plant Soil 406:15-27

Querejeta JI, Egerton-Warburton LM, Allen MF (2003) Direct nocturnal water transfer from Oaks to their mycorrhizal symbionts during severe soil drying. Oecologia 134:55-65

Querejeta JI, Egerton-Warburton LM, Prieto I et al (2012) Changes in soil hyphal abundance and viability can alter the patterns of hydraulic redistribution by plant roots. Plant Soil 355:63-73

Rao MR, Nair PKR, Ong CK (1998) Biophysical interactions in tropical agroforestry systems. Agrofor Syst 38:3-50

Ravenek JM, Mommer L, Visser EJW, van Ruijven J, van der Paauw JW, Smit-Tiekstra A, de Caluwe H, de Kroon H (2016) Linking root traits and competitive success in grassland species. Plant Soil 407:39-53

Reich PB (2014) The world-wide'fast-slow' plant economics spectrum: a traits manifesto. J Ecol 102:275-301

Richards JH, Caldwell MM (1987) Hydraulic lift: substantial nocturnal water transport between layers by Artemisia tridentata roots. Oecologia 73:486-489

Roupsard O, Ferh A, Granier A, Pallo F, Depommier D, Mallet B, Joly HJ, Dreyer E (1999) Reverse phenology and dry-season water uptake by Faidherbia albida (Del.) A. Chev. in a agroforestry parkland of Sudanese West Africa. Funct Ecol 13:450-472

Rowe EC, Hairiah K, Giller KE, van Noordwijk M, Cadisch G (1999) Testing the safety-net role of hedgerow tree roots by $15 \mathrm{~N}$ placement at different soil depths. Agrofor Syst 43:81-93

Ruhigwa BA, Gichuru MP, Mambani B, Tariah NM (1992) Root distribution of Acioa barteri, Alchornea cordifolia, Cassia siamea and Gmelina arborea in an acid Ultisol. Agrofor Syst 19:67-78

Ryan PR, Delhaize E, Watt M, Richardson AE (2016) Plant roots: understanding structure and function in an ocean of complexity. Ann Bot 118:555-559

Scholz FG, Bucci SJ, Goldstein G et al (2008) Biophysical and life-history determinants of hydraulic lift in Neotropical savanna trees. Funct Ecol 22:773-786

Schroth G (1995) Tree root characteristics as criteria for species selection and systems design in agroforestery. Agrofor Syst 30:125-143

Schroth G (1998) A review of belowground interactions in agroforestry, focussing on mechanisms and management options. Agrofor Syst 43(1-3):5-34 
Schroth G, Lehmann G (1995) Contrasting effects of roots and mulch from three agroforestry tree species on yields of alley cropped maize. Agric Ecosyst Environ 54:89-101

Sekiya N, Yano K (2004) Do pigeon pea and sesbania supply groundwater to intercropped maize through hydraulic lift?Hydrogen stable isotope investigation of xylem waters. Field Crop Res 86:167-173

Sekiya N, Araki H, Yano K (2011) Applying hydraulic lift in an agroecosystem: forage plants with shoots removed supply water to neighboring vegetable crops. Plant Soil 341:39-50

Shen Y, Zhang Y, Li S (2011) Nutrient effects on diurnal variation and magnitude of hydraulic lift in winter wheat. Agric Water Manag 98:1589-1594

Singh V (1994) Morphology and pattern of root distribution in Prosopis cineraria, Dalbergia sissoo and Albizia lebbeck in an arid region of north-western India. Trop Ecol 35(1):133146

Siriri D, Ong CK, Wilson J, Boffa JM, Black CR (2010) Tree species and pruning regime affect crop yield on bench terraces in SW Uganda. Agrofor Syst 78:65-77

Siriri D, Wilson J, Coe R, Tenywa MM, Bekunda MA, Ong CK, Black CR (2012) Water storage and soil evaporation under agroforestry systems and sole crops on bench terraces in SW Uganda. Agrofor Syst 87:45-58

Siriri D, Wilson J, Coe R, Tenywa MM, Bekunda MA, Ong CK, Black CR (2013) Trees improve water storage and reduce soil evaporation in agroforestry systems on bench terraces in SW Uganda. Agrofor Syst 87:45-58

Smart DR, Carlisle E, Goebel M, Nuñez BA (2005) Transverse hydraulic redistribution by a grapevine. Plant Cell Environ 28:157-166

Smith DM, Jarvis PG, Odongo JCW (1997) Sources of water used by trees and millet in Sahelian windbreak systems. J Hydrol 198:140-153

Smith DM, Jackson NA, Roberts JM, Ong CK (1999) Reverse flow of sap in tree roots and downward siphoning of water by Grevillea robusta. Funct Ecol 13:256-264

Steudle E (2000) Water uptake by plant roots: an integration of views. Plant Soil 226:45-56

Steudle E (2001) The cohesion-tension mechanism and the acquisition of water by plant roots. Annu Rev Plant Physiol Plant Mol Biol 52:847-875

Sun S-J, Meng P, Zhang J-S, Wan X (2014) Hydraulic lift by Juglans regia relates to nutrient status in the intercropped shallow-root crop plant. Plant Soil 374:629-641

Suprayogo D, van Noordwijk M, Hairiah K, Cadisch G (2002) The 'safety-net' of an acrisol: measuring and modelling retarded leaching of mineral nitrogen. Eur J Soil Sci 53: 185-194

Tracy SR, Mooney SJ, Sturrock CJ, Mairhofer S, Al-Traboulsi M, Bennett MJ, Pridmore TP, Lynch JP, Wells DM (2015) Laboratory and field techniques for measuring root distribution and architecture. In: Ong CK, Black CR, Wilson J (Eds)Tree-crop interactions: Agroforestry in a changing climate. 2nd Edition, C.A.B International, pp 258-277

Vadez V, Kholová J, Yadav RS, Hash CT (2013) Small temporal differences in water uptake among varieties of pearl millet (Pennisetum glaucum (L.) R. Br.) are critical for grain yield under terminal drought. Plant Soil 371:447-462

van Noordwijk M (1993) Roots: length, biomass, production and mortality. In: Anderson JM, Ingram JSI (eds) Tropical Soil
Biology and Fertility. A handbook of methods. Second Edition, Oxford, pp 132-144

van Noordwijk M, Ong CK (1999) Can the ecosystem mimic hypotheses be applied to farms in African savannahs? Agrofor Syst 45(1-3):131-158

van Noordwijk M, Purnomosidhi P (1995) Root architecture in relation to tree-soil-crop interactions and shoot pruning in agroforestry. Agrofor Syst 30:61-173

van Noordwijk M, van de Geijn SC (1996) Root, shoot and soil parameters required for process-oriented models of crop growth limited by water or nutrients. Plant Soil 183(1):1-25

van Noordwijk M, Rahayu S, Williams SE, Hairiah K, Khasanah N, Schroth G (2004) Crop and tree root-system dynamics. In: van Noordwijk M, Cadisch G, Ong CK (eds) Belowground Interactions in Tropical Agroecosystems. CAB International, Wallingford, pp 83-107

van Noordwijk M, Lawson G, Hairiah K, Wilson JR (2015) Root distribution of trees and crops: competition and/or complementarity. In: Black C, Wilson J, Ong CK Tree-Crop Interactions: Agroforestry in a Changing Climate. CABI, Wallingford, pp 221-257

Vanlauwe B, Akinnifesi FK, Tossah BK, Lyasse O, Sanginga N, Merckx R (2002) Root distribution of Senna siamea grown on a series of derived-savanna-zone soils in Togo, West Africa. Agrofor Syst 54:1-12

Vogt KA, Vogt DJ, Bloomfield J (1998) Analysis of some direct and indirect methods for estimating root biomass and production of forests at an ecosystem level. Plant Soil 200:71-89

Wajja-Musukwe T-N, Wilson J, Sprent JI, Ong CK, Deans D, Okorio J (2008) Tree growth and management in Ugandan agroforestry systems: effects of root pruning on tree growth and crop yield. Tree Physiol 28:233-242

Wan C, Xu W, Sosebee RE, Machado S, Archer T (2000) Hydraulic lift in drought-tolerant and -susceptible maize hybrids. Plant Soil 219:117-226

Wang ZH, Fang H, Chen M (2017) Effects of root exudates of woody species on the soil anti-erodibility in the rhizosphere in a karst region, China. PeerJ 5:e3029. https://doi. org/10.7717/peerj.3029

Warren JM, Meinzer FC, Brooks JR, Domec JC (2005) Vertical stratification of soil water storage and release dynamics in pacific northwest coniferous forests. Agric For Meteorol 130: 39-58

Warren JM, Meinzer FC, Brooks JR, Domec JC, Coulombe R (2007) Hydraulic redistribution of soil water in two oldgrowth coniferous forests: quantifying patterns and controls. New Phytol 173:753-765

Warren JM, Brooks JR, Meinzer FC, Eberhart JL (2008) Hydraulic redistribution of water from Pinus ponderosa trees to seedlings: evidence for an ectomycorrhizal pathway. New Phytol 178:382-394

Yoder CK, Nowak RS (1999) Hydraulic lift among native plant species in the Mojave desert. Plant Soil 215:93-102

Publisher's note Springer Nature remains neutral with regard to jurisdictional claims in published maps and institutional affiliations. 